\title{
Y-12 NATIONAL SECURITY COMPLEX BIOLOGICAL MONITORING AND ABATEMENT PROGRAM PLAN
}

January 2013

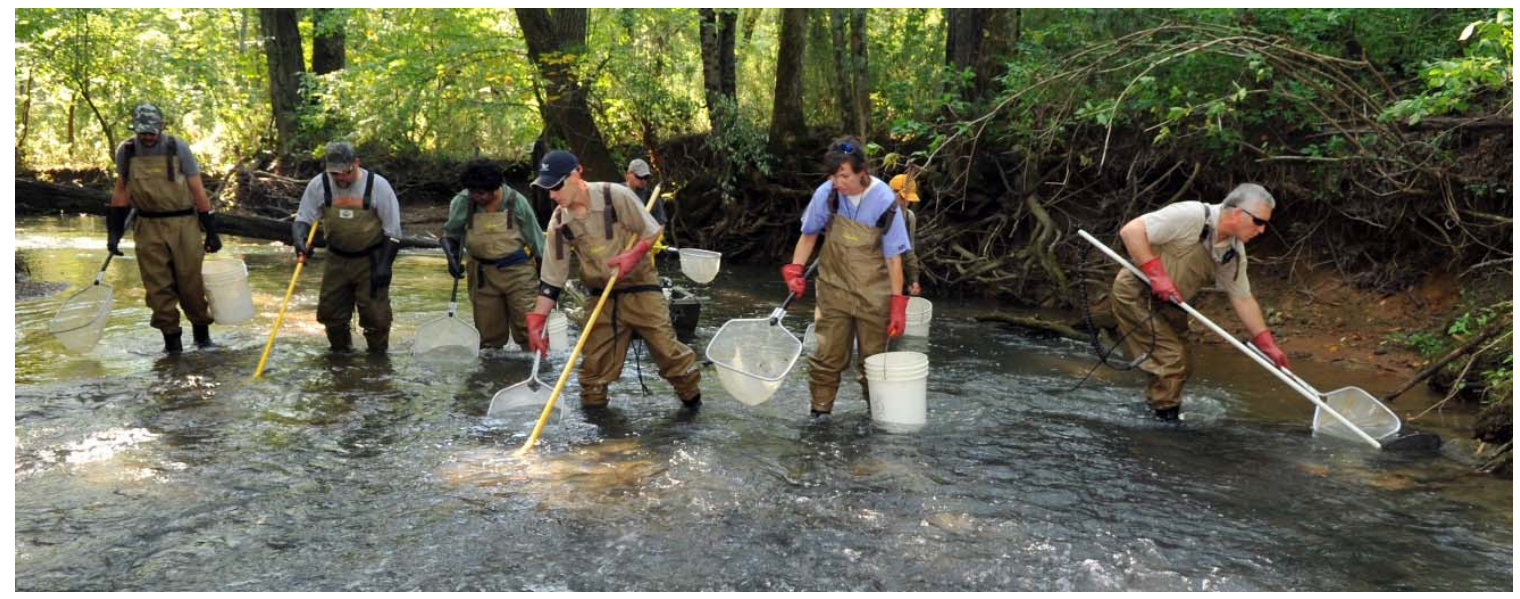

M.J. Peterson

T.J. Mathews

M.G. Ryon

J.G. Smith

S.W. Christensen

M.S. Greeley, Jr.

W.K. Roy

C.C. Brandt

K.A. Sabo
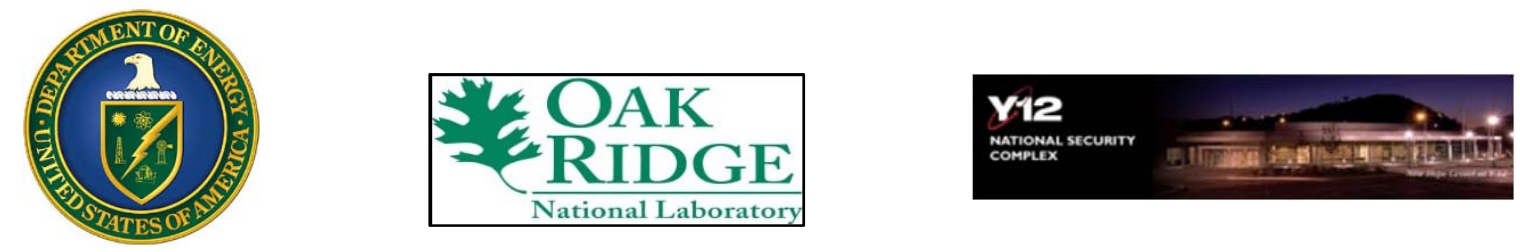

This document was prepared in conjunction with work under Contract No. DE-AC05-00OR22725 with the U.S. Department of Energy. 
Cover photo: Biological Monitoring and Abatement Program staff collecting fish in East Fork Poplar Creek, Oak Ridge, Tennessee. Photo taken on September 12, 2011 by J. Miles

Cary/Knoxville News Sentinel. Used by permission.

\section{DOCUMENT AVAILABILITY}

Reports produced after January 1, 1996, are generally available free via the U.S. Department of Energy (DOE) Information Bridge.

Web site http://www.osti.gov/bridge

Reports produced before January 1, 1996, may be purchased by members of the public from the following source.

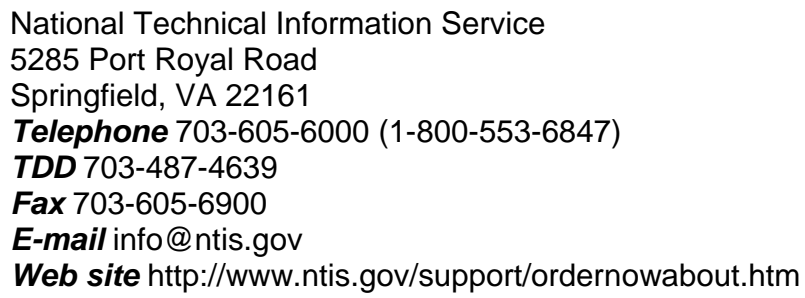

Reports are available to DOE employees, DOE contractors, Energy Technology Data Exchange (ETDE) representatives, and International Nuclear Information System (INIS) representatives from the following source.

Office of Scientific and Technical Information

P.O. Box 62

Oak Ridge, TN 37831

Telephone 865-576-8401

Fax 865-576-5728

E-mail reports@osti.gov

Web site http://www.osti.gov/contact.html

This report was prepared as an account of work sponsored by an agency of the United States Government. Neither the United States Government nor any agency thereof, nor any of their employees, makes any warranty, express or implied, or assumes any legal liability or responsibility for the accuracy, completeness, or usefulness of any information, apparatus, product, or process disclosed, or represents that its use would not infringe privately owned rights. Reference herein to any specific commercial product, process, or service by trade name, trademark, manufacturer, or otherwise, does not necessarily constitute or imply its endorsement, recommendation, or favoring by the United States Government or any agency thereof. The views and opinions of authors expressed herein do not necessarily state or reflect those of the United States Government or any agency thereof. 


\title{
Y-12 National Security Complex Biological Monitoring and Abatement Program Plan
}

\author{
M. J. Peterson \\ T. J. Mathews \\ M. G. Ryon \\ J. G. Smith \\ S.W. Christensen \\ M.S. Greeley, Jr. \\ W.K. Roy \\ C.C. Brandt \\ K.A. Sabo
}

January 2013

Prepared by

Environmental Sciences Division

OAK RIDGE NATIONAL LABORATORY

Oak Ridge, Tennessee 37831

managed by

UT-BATTELLE, LLC

for the

U.S. DEPARTMENT OF ENERGY

under contract DE-AC05-00OR22725

\author{
Prepared for \\ Environmental Compliance Department \\ Y-12 NATIONAL SECURITY COMPLEX \\ Oak Ridge, Tennessee \\ managed by \\ B\&W Y-12 \\ for the \\ U.S. DEPARTMENT OF ENERGY \\ under contract DE-AC05-00OR22800
}

This document is available through the U.S. Department of Energy Office of Scientific and Technical Information (OSTI) at www.osti.gov 
\{“blank” page 
Y-12 National Security Complex Biological Monitoring and Abatement Program Plan

TABLE OF CONTENTS

$\begin{array}{ll} & \text { Page } \\ \text { LIST OF FIGURES } & \mathrm{v} \\ \text { LIST OF TABLES } & \mathrm{v} \\ \text { ACRONYMS AND ABBREVIATIONS } & \text { vii } \\ \text { EXECUTIVE SUMMARY } & \text { ix } \\ \text { INTRODUCTION } & 1 \\ \text { BACKGROUND } & \\ \text { Description of Study Area } & 2 \\ \text { Creek Impairments } & 2 \\ \text { Pollution Abatement Action } & 4 \\ & 4 \\ \text { MONITORING APPROACH } & 4 \\ \text { Rationale } & 4 \\ \text { Methods } & 7 \\ \text { Sampling Sites and Frequencies } & 13 \\ & \\ \text { PROGRAM INTEGRATION } & 16 \\ \text { Approach } & 16 \\ \text { Organization } & 17 \\ \text { Data Management } & 17 \\ \text { Quality Assurance } & 19 \\ \text { Reporting } & 20 \\ \text { REFERENCES } & 21 \\ \end{array}$


\{“blank” page 


\section{LIST OF FIGURES}

Fig. 1. The Y-12 BMAP’s East Fork Poplar Creek sampling sites

Fig. 2. Location of biological monitoring reference sites in relation to the Oak Ridge Y-12 Complex

Fig. 3. Timeline showing major pollution abatement actions at the Y-12 National Security Complex, 1984-2011

Fig. 4. A biopsy plug being taken from a redbreast sunfish (top), and Passive Integrated Transponder (PIT) tag equipment (bottom) for identifying fish recaptures

Fig. 5. Benthic macroinvertebrate community task sampling using a Hess sampler (left), TDEC protocol laboratory sorting (top right), and taxa identification (bottom right)

Fig. 6. Setting seine nets for the fish community task (left), backpack electrofishing (top right), and processing fish (bottom right)

\section{LIST OF TABLES}

Table 1. Tennessee Department of Environment and Conservation's (TDEC) listing of impacted water bodies downstream of Y-12 Complex, per TDEC’s proposed final version 2010 303d list (TDEC 2010)

Table 2. Summary of the biological monitoring tasks, organisms sampled, field and laboratory methods, and key calculated metrics for the Y-12 Biological Monitoring and Abatement Program

Table 3. Summary of the 2012 Y-12 Biological Monitoring and Abatement Program Plan's sampling locations and annual frequencies 
\{“blank” page\} 


\section{ACRONYMS AND ABBREVIATIONS}

\begin{tabular}{|c|c|}
\hline AEL & Aquatic Ecology Laboratory \\
\hline ASER & Annual Site Environmental Report \\
\hline BCK & Bear Creek Kilometer \\
\hline BFK & Brushy Fork Kilometer \\
\hline BMAP & Biological Monitoring and Abatement Program \\
\hline CERCLA & Comprehensive Environmental Response, Compensation, and Liability Act \\
\hline CRK & Clinch River Kilometer \\
\hline D\&D & Decontamination and Decommissioning \\
\hline DMR & Discharge Monitoring Report \\
\hline DoD & Department of Defense \\
\hline DOE & U.S. Department of Energy \\
\hline ECD & Environmental Compliance Department \\
\hline EFK & East Fork Poplar Creek kilometer \\
\hline EFPC & East Fork Poplar Creek \\
\hline EPA & U. S. Environmental Protection Agency \\
\hline ESD & Environmental Sciences Division \\
\hline HCK & Hinds Creek Kilometer \\
\hline IBI & Index of Biotic Integrity \\
\hline MCK & McCoy Branch Kilometer \\
\hline NPDES & National Pollutant Discharge Elimination System \\
\hline OREIS & Oak Ridge Environmental Information System \\
\hline ORNL & Oak Ridge National Laboratory \\
\hline ORR & Oak Ridge Reservation \\
\hline ORTF & Oak Ridge Task Force \\
\hline
\end{tabular}




\section{ACRONYMS AND ABBREVIATIONS (cont'd)}

ORWTF Oak Ridge Wastewater Treatment Facility

PAH Polycyclic Aromatic Hydrocarbons

PCB Polychlorinated Biphenyl

PCK Poplar Creek Kilometer

PIT Passive Integrated Transponder

QAP Quality Assurance Program

QAPP Quality Assurance Project Plan

QA/QC Quality Assurance/Quality Control

QMS Quality Management System

RER Remediation Effectiveness Report

RMPE Reduction of Mercury in Plant Effluents

RTL Ready-to-Load

SAS Statistical Analysis System

SBMS Standards-Based Management System

SOPs Standard Operating Procedures

SQKICK Semi-Quantitative Riffle-Kick

TDEC Tennessee Department of Environment and Conservation

TOA Tennessee Oversight Agreement

UEFPC Upper East Fork Poplar Creek

WEMA West End Mercury Area

WPC Water Pollution Control

Y-12 Complex Y-12 National Security Complex 


\section{Y-12 National Security Complex Biological Monitoring and Abatement Program Plan Executive Summary}

This document provides the Biological Monitoring and Abatement Program (BMAP) Plan for East Fork Poplar Creek (EFPC), as required by the Y-12 National Security Complex (Y-12 Complex) National Pollutant Discharge Elimination System (NPDES) permit which became effective December 1, 2011. The BMAP was first developed in 1985 by staff in the Environmental Science Division at the Oak Ridge National Laboratory at the request of the Y-12 Complex. The multidisciplinary and quantitative biological monitoring approaches used for the BMAP were developed, from the beginning, in close consultation with Y-12 Complex Environmental Compliance staff, as well as the State of Tennessee and the Environmental Protection Agency. A draft BMAP Plan was submitted to the Tennessee Department of Environment and Conservation (TDEC) in May 2012 and was approved by TDEC with revision in December 2012. The TDEC's Plan changes are incorporated in this final BMAP Plan issued in January 2013. The general approach to the 2013 BMAP Plan follows previous precedent, and addresses all BMAP-related NPDES permit requirements.

The focus of the monitoring effort is on EFPC and comparable reference streams, including Brushy Fork and Hinds Creek. Two other stream systems near the Y-12 Complex, Bear Creek and McCoy Branch, are similarly monitored using BMAP and TDEC protocols as required in the permit; however, these streams are monitored by Comprehensive Environmental Response, Compensation, and Liability Act -funded programs and are only briefly summarized in this Plan. Three major tasks comprise the current program: fish bioaccumulation, benthic macroinvertebrate community, and fish community. A concomitant task, toxicity testing of storm drains, is also implemented at the Y-12 Complex and briefly described in the Plan. Each BMAP task differs slightly in the number of sites and frequency of sampling, depending on need as determined by previous monitoring. Sampling rationale and specific methods for each task are provided herein. A summary of program integration components, including data management, quality assurance, and reporting aspects, are also provided.

The BMAP is an internationally recognized biological monitoring program that is a valuable case study for the U.S. Department of Energy (DOE) and the nation. First and foremost, the program evaluates Tennessee Water Quality Criteria (as required in the NPDES permit) by conducting studies to annually evaluate bioaccumulation of contaminants of concern, and the receiving streams' biological integrity. The program has been successful in evaluating ecological effects and their causes, and has provided actionable information in the design and application of pollution abatement actions. Most importantly, the program design focuses on assessing spatial and temporal change, and has documented substantial ecological recovery in response to various facility actions. The program results have therefore become a key measure of how well the DOE facilities are doing relative to protecting the environment, and provide assurance to regulators and the public that stream conditions are improving. The DOE's mission and environmental management in Oak Ridge will continue to evolve as the facilities modernize and various decontamination and decommissioning activities and pollution abatement actions are implemented. Many changes are expected at the Y-12 Complex in the next few years that have the potential to positively affect, or on a short-term basis negatively affect, the stream environment. The BMAP approach described here will continue to provide an important integrated measure of receiving stream conditions and ecological response to future facility actions. 
\{“blank" page 


\section{INTRODUCTION}

In May 1985, a National Pollutant Discharge Elimination System (NPDES) permit was issued for the Y12 National Security Complex (Y-12 Complex), formerly the Oak Ridge Y-12 Plant, located in Oak Ridge, Tennessee. As a condition of the permit, a Biological Monitoring and Abatement Program (BMAP) was developed to demonstrate that the effluent limitations established for the Y-12 Complex protect the classified uses of the receiving stream, East Fork Poplar Creek (EFPC), in particular, the growth and propagation of fish and aquatic life (Loar et al. 1989). A second objective of the BMAP was to document the ecological effects resulting from the implementation of a water pollution control program designed to eliminate direct discharges of wastewaters to EFPC and to minimize the inadvertent release of pollutants to the environment. Because of the complex nature of the discharges to EFPC and the temporal and spatial variability in the composition of the discharges, a comprehensive, integrated approach to biological monitoring was developed. The objectives of the BMAP remain important today because of ongoing and changing programs and activities at the Y-12 Complex.

Since its inception in 1985, the Y-12 BMAP has helped guide successful pollution abatement measures at the Y-12 Complex, resulting in substantial improvements in ecological conditions within the stream. Over time, the diversity and abundance of aquatic life in EFPC have improved steadily, fish kills have become increasingly rare, and water is no longer toxic at sites sampled using regulatory wet testing methods. Actions implemented in the 1980s and 1990s through the Reduction of Mercury in Plant Effluents (RMPE) program, including stream bank stabilization and routing of EFPC flow around Lake Reality, resulted in reduced inputs of mercury or reduced methylation of mercury in EFPC. Recent actions to reduce mercury releases at the Y-12 Complex include construction and operation of the Big Springs Water Treatment System, mercury contaminated soil removal at the Old Salvage Yard, and storm drain cleanout and relining activities in the West End Mercury Area (WEMA). Information obtained from the BMAP (e.g., if fish mercury levels decrease) provides feedback on the effectiveness of pollution abatement actions, and whether ecological conditions in EFPC continue to improve.

Although substantial improvement has been accomplished, ecological conditions in EFPC remain depressed relative to numerical standards set by the Tennessee Department of Environment and Conservation (TDEC) as indicative of a system fully meeting its classified use for the propagation of fish and aquatic life. The degree of deviation from optimum conditions is greatest in the headwaters, upstream from the effects of urban development. Both fish and aquatic invertebrate communities in Upper East Fork Poplar Creek (UEFPC) lack key species indicative of unimpaired aquatic systems and are numerically dominated by pollution- tolerant organisms. In addition to addressing regulatory requirements, the current BMAP has been developed to assess the impacts of Y-12 Complex operations (past and present) on the biota of EFPC, to document the ecological effects of pollution abatement actions, and to investigate the causes of continuing impacts. A key aspect of the program is to provide feedback to Y-12 Complex staff regarding potential operational changes or solutions that may limit negative impact or improve ecological conditions in the stream.

TDEC's current renewed NPDES permit for the Y-12 Complex became effective on December 1, 2011. This BMAP Plan meets the requirements of the renewed permit, which requires assessment of bioaccumulation and the receiving stream's biological integrity. Relative to the previous BMAP Plan, the scope of the biological integrity assessment has not changed from current, but some minor changes were 
made to the bioaccumulation monitoring effort to better evaluate mercury and to reduce focus on PCB monitoring. In addition the BMAP-related toxicity testing effort was reduced one third from previous (3 sites to 2 sites annually). Plan revisions are based on (1) an assessment of current monitoring results and assessment needs, and (2) the need to evaluate the effects of continuing changes in the composition of discharges resulting from scheduled pollution abatement actions as well as facility modernization activities at the Y-12 Complex.

\section{BACKGROUND}

\section{Description of the Study Area}

The study area is located in the Valley and Ridge physiographic province of the Southern Appalachians. The EFPC drainage basin is located near the northern boundary of the U.S. Department of Energy's (DOE) Oak Ridge Reservation (ORR) and has an area of $77.2 \mathrm{~km}^{2}$ from the headwaters to the mouth at Poplar Creek (Fig. 1). Elevations in the basin range from 226 to 390 meters. Parallel northeast-trending ridges constitute the northern (Black Oak Ridge) and southern (Chestnut Ridge) boundaries of the watershed. The ridges are composed primarily of sandstones and dolostones and the valleys are underlain by shales, limy shales, and limestones (Geraghty and Miller, Inc. 1985). The principal groundwaterbearing formation in the Oak Ridge area is the Knox Dolomite which comprises 25 percent of the surface area of the EFPC drainage basin; another 32 percent of the area consists of Chickamauga Limestone.

The primary reference area used in the BMAP is the Brushy Fork watershed located just north of Oak Ridge and adjacent to the EFPC watershed (Fig. 2). The two drainages, which are separated by Black Oak Ridge, have a similar geologic composition. The Knox Dolomite that underlies Black Oak Ridge is the source of three large springs that are tributaries to Brushy Fork above the study site (BFK 7.6). The almost identical unit-area, low-flow discharges $\left(\sim 0.95 \mathrm{~L} 3 \cdot \mathrm{sec}-1 \cdot \mathrm{km}^{-}{ }^{2}\right)$ of EFPC at EFK 5.3 and Brushy Fork at BFK 10.1 provide additional evidence of the similarity in their geologic composition (Loar et al. 1992). Hinds Creek provides an additional local reference stream notable for its relatively low mercury and PCB concentrations in fish (Fig. 2).

EFPC is fed in part by springs on the northwest slope of Chestnut Ridge. Spring water enters the Y-12 Complex storm drain network where it mixes with facility-generated waters (primarily cooling water) and shallow subsurface groundwater before exiting Outfall 200, at the western terminus of the creek.

Approximately 3-4 million gallons of raw water per day is pumped from the Clinch River and added to EFPC at a point approximately $15 \mathrm{~m}$ below Outfall 200. The additional water from the Clinch River allows EFPC flow to be managed currently at a minimum flow of 5 million gallons per day (mgd) at Station 17 (near EFK 23.4, Fig. 1), as required in the NPDES Permit.

Another key feature of the stream environment near the Y-12 Complex is the presence of a lined basin, Lake Reality, which receives stream inputs during very high flows (and also discharges back to the creek on the other side of the basin during those high flow events). Under normal flow conditions, since 1998, stream water flows around the basin in a concrete diversion channel. Because the elevation of the diversion channel is higher than that of EFPC, the outfall from the channel creates a small waterfall that is an effective barrier to upstream fish movement. 


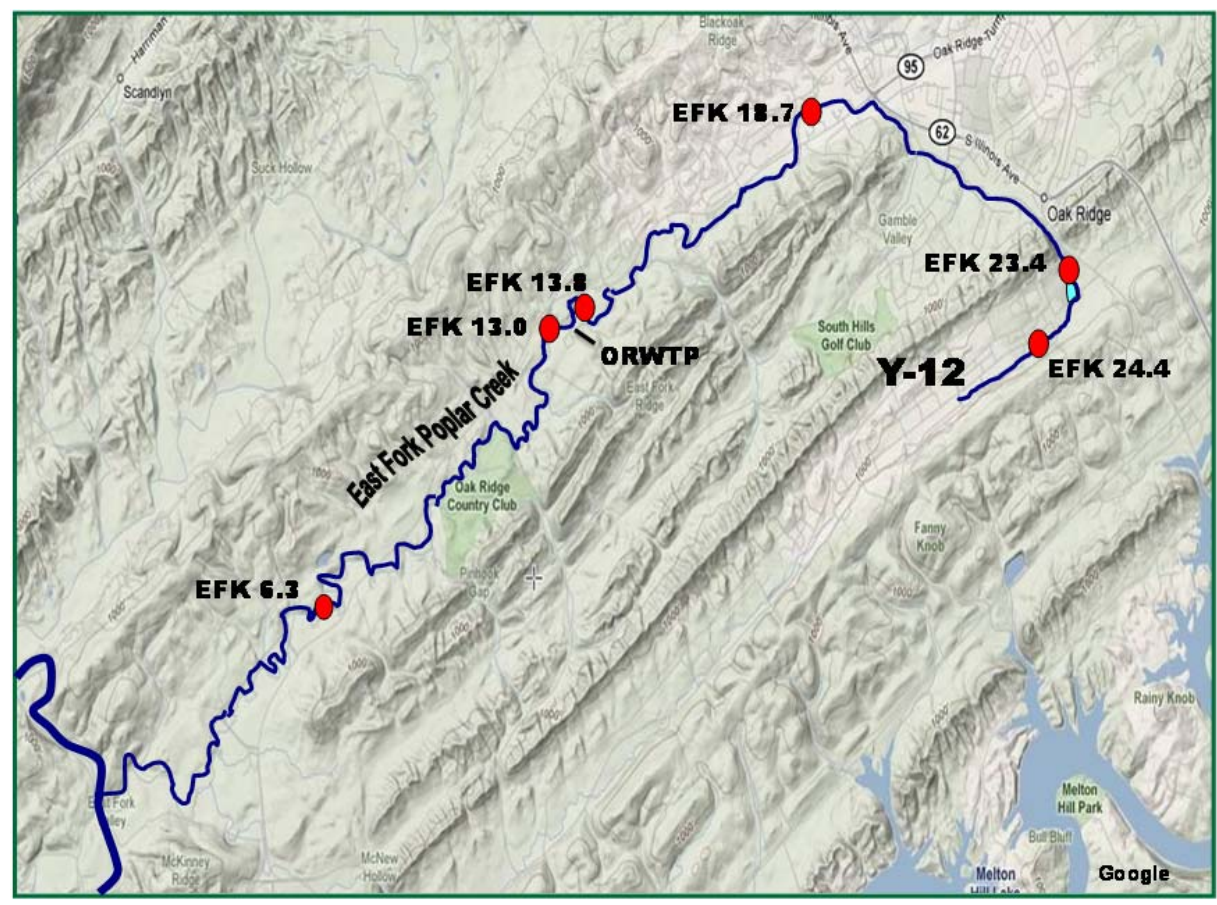

Fig. 1. The Y-12 BMAP's East Fork Poplar Creek sampling sites. Numbers refer to approximate kilometer distance upstream of the confluence of East Fork Poplar Creek and Poplar Creek.

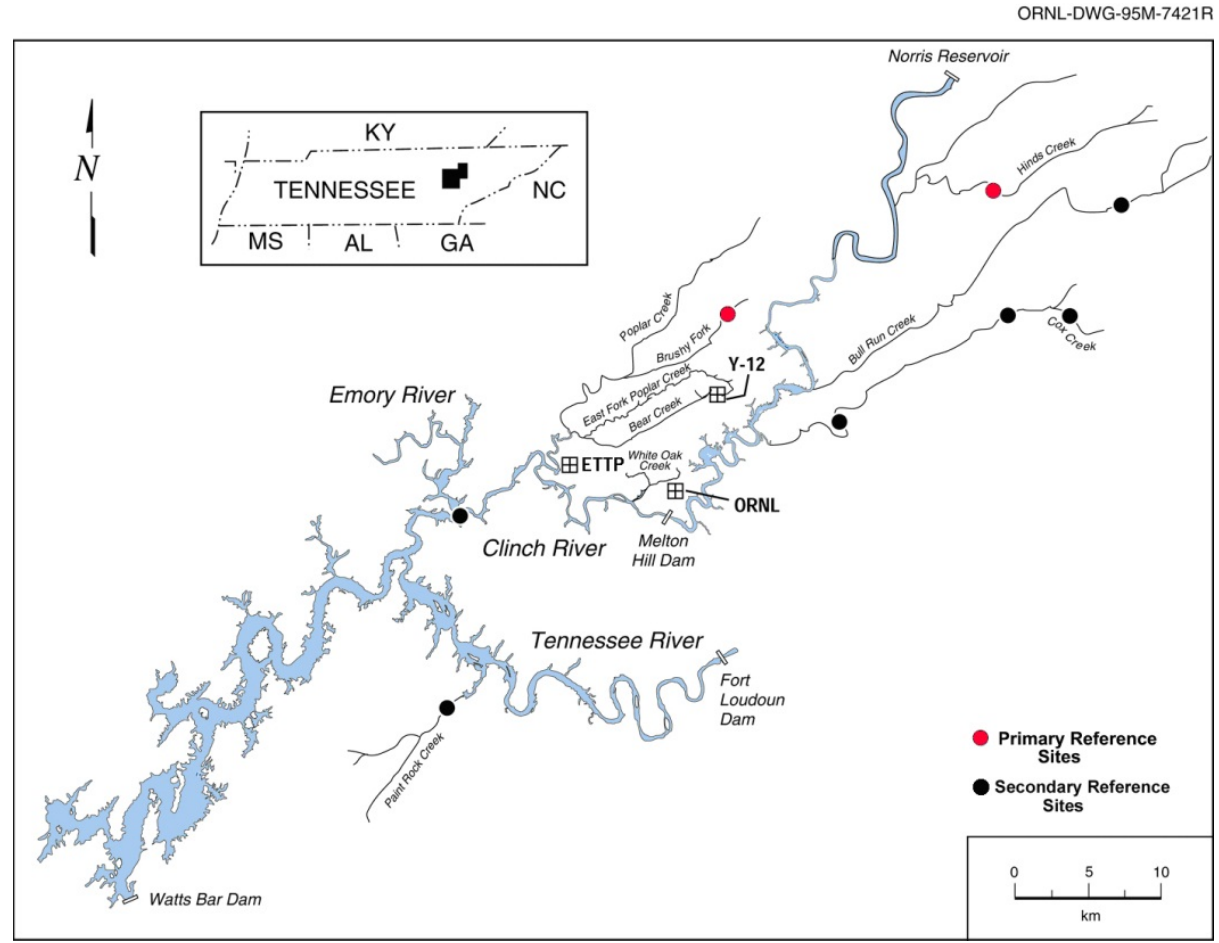

Fig. 2. Location of biological monitoring reference sites in relation to the Oak Ridge Y-12 Complex. 
The creek flows less than $1 \mathrm{~km}$ below Lake Reality before leaving the ORR at EFK 22.7. For the next 15 $\mathrm{km}$, EFPC flows through the city of Oak Ridge, before crossing the ORR boundary again at EFK 7.7 for the remainder of its course. The lower portion of the watershed within the ORR is largely undeveloped in the stream's riparian zones, and consists mostly of mixed hardwood stands.

\section{Creek Impairments}

The Y-12 Complex is a large industrial facility that has been in operation since the 1940s. Varying and complex operations over the years have resulted in legacy contamination of area soils, groundwater, sediment, and surface waters. The stream stressors or contaminants of most concern historically at the site have been chlorine, mercury, PCBs, nutrient loading, hydrological regime alteration, miscellaneous spills, and habitat-related factors (Peterson et al. 2011).

Much has been written about water quality impairments to EFPC and historical detail is not repeated here. Recent sources of detailed written material include a review of Y-12 Complex environmental problems and pollution abatement actions (Loar et al. 2011), a historical summary of changes in EFPC water quality (Stewart et al. 2011), and a history of mercury use and contamination at the Y-12 Complex (Brooks and Southworth 2011). EFPC and other surface waters downstream continue to be included on the State of Tennessee's 303d list of impaired aquatic systems (Table 1).

\section{Pollution Abatement Actions}

Many pollution abatement actions have been implemented at the Y-12 Complex during the past 26 years, as detailed in Loar et al. 2011. These actions have resulted in substantial improvements in the level of contaminant release from the facility as well as the ecological health of EFPC as documented by the BMAP. A summary of some of the major actions at Y-12 designed to positively affect the stream environment is provided in Fig. 3.

\section{MONITORING APPROACH}

\section{Rationale}

The Y-12 BMAP consists of three major monitoring tasks that reflect different but complementary approaches to evaluating the effects of the Y-12 Complex discharges on the biotic integrity of EFPC. These monitoring tasks include (1) fish bioaccumulation, (2) benthic macroinvertebrate community, and (3) fish community. A task required in the permit that is closely related to the in-stream monitoring is wet toxicity testing of effluents using fathead minnows (Pimephales promelas) and water fleas (Ceridaphnia dubia) at outfall 200 and outfall 135. The annual toxicity testing results are used as needed in interpretation of BMAP results; however, because toxicity testing requirements are described in detail in the permit and the toxicity testing reports are done separately, toxicity task detail is not provided in this Plan. The advantages and disadvantages of BMAP tasks, as well as previously used components of the Y-12 BMAP, were recently evaluated in a special issue of the international journal "Environmental Management” (Peterson 2011). The multidisciplinary and quantitative approaches were found to be especially useful for evaluating recovery and responsiveness to facility pollution abatement actions. Most importantly, EFPC is listed by TDEC as impaired because of high concentrations of mercury and PCBs in fish, and loss of biological integrity; the three tasks in this Plan are therefore the most applicable to TDEC regulatory requirements. 
Table 1. Tennessee Department of Environment and Conservation's (TDEC) listing of impacted water bodies downstream of Y-12 Complex, per TDEC's proposed final version $2010303 d$ list

(TDEC 2010).

\begin{tabular}{|c|c|c|c|c|}
\hline $\begin{array}{l}\text { Impacted } \\
\text { Waterbody }\end{array}$ & County & $\begin{array}{l}\text { Miles/Acre } \\
\text { Impaired }\end{array}$ & Cause & Pollutant Source \\
\hline $\begin{array}{l}\text { East Fork } \\
\text { Poplar Creek }\end{array}$ & $\begin{array}{l}\text { Anderson } \\
\text { /Roane }\end{array}$ & 11.3 & $\begin{array}{l}\text { PCBs } \\
\text { Mercury } \\
\text { Escherichia coli } \\
\text { Loss of biological } \\
\text { integrity due to siltation } \\
\text { Nutrients } \\
\text { Other anthropogenic } \\
\text { habitat alterations }\end{array}$ & $\begin{array}{l}\text { Industrial Point Source } \\
\text { Contaminated Sediments } \\
\text { High Density Municipal } \\
\text { Area }\end{array}$ \\
\hline $\begin{array}{l}\text { East Fork } \\
\text { Poplar Creek }\end{array}$ & Roane & 9.7 & $\begin{array}{l}\text { PCBs } \\
\text { Mercury } \\
\text { Escherichia coli } \\
\text { Loss of biological } \\
\text { integrity due to siltation } \\
\text { Nitrates } \\
\text { Phosphates }\end{array}$ & $\begin{array}{l}\text { Industrial Point Source } \\
\text { Municipal Point Source } \\
\text { Contaminated Sediments } \\
\text { Collection System Failure } \\
\text { High Density Municipal } \\
\text { Area }\end{array}$ \\
\hline $\begin{array}{l}\text { Poplar Creek } \\
\text { Embayment, } \\
\text { Watts Bar } \\
\text { Reservoir }\end{array}$ & Roane & $141 \mathrm{ac}$ & $\begin{array}{l}\text { PCBs } \\
\text { Mercury }\end{array}$ & $\begin{array}{l}\text { Industrial Point Source } \\
\text { Contaminated Sediments }\end{array}$ \\
\hline $\begin{array}{l}\text { Watts Bar } \\
\text { Reservoir, } \\
\text { Clinch River } \\
\text { Arm }\end{array}$ & Roane & 2336 ac & $\begin{array}{l}\text { PCBs } \\
\text { Chlordane } \\
\text { Mercury }\end{array}$ & $\begin{array}{l}\text { Industrial Point Source } \\
\text { Contaminated Sediments } \\
\text { Atmospheric deposition }\end{array}$ \\
\hline
\end{tabular}



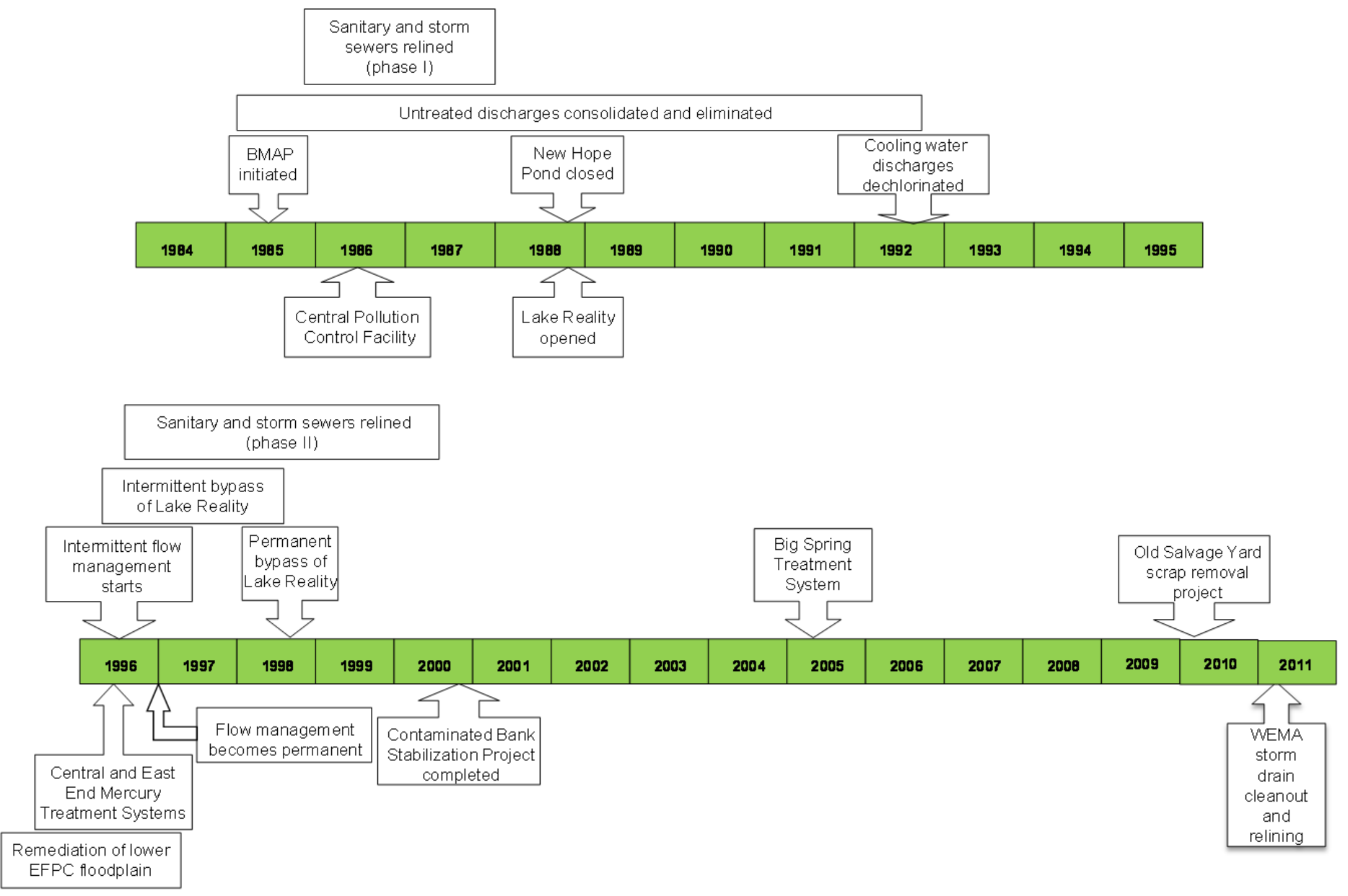

Fig. 3. Timeline showing major pollution abatement actions at the Y-12 National Security Complex, 1984-2011. 
As of fall 2011, the three BMAP tasks continue to document multiple stream impairments, especially in the upper sections of the stream, justifying continued biological monitoring. Fish exceed human health and ecological risk thresholds, and benthic macroinvertebrate and fish community monitoring continue to indicate impairment relative to regional reference streams or TDEC biological integrity criteria.

Each task provides unique and valuable information of relevance to environmental assessment of EFPC:

- Bioaccumulation studies are an important aspect of biological monitoring programs, as these studies indicate exposure of contaminants as well as potential risk. Contaminants from the Y-12 Complex may be accumulated in organism tissues resulting in exposure and impacts further up the food chain (e.g., in man or terrestrial wildlife species). Previous studies have indicated that contaminants commonly measured in biota, such as mercury, zinc, Polycyclic Aromatic Hydrocarbons (PAHs), and PCBs, could be negatively affecting aquatic organisms in EFPC, although the importance of these contaminants in relation to other factors is not well understood (Loar et al. 1992, Hinzman et al. 1993, Ham et al. 1997). Monitoring of EFPC has identified mercury and PCBs as the primary substances that accumulate to levels in fish and pose health concerns to human consumers as well as terrestrial wildlife (Loar et al. 1992, Hinzman et al. 1993, Sample et al. 1996). In addition to mercury and PCBs, metals other than mercury continue to be elevated in periphyton (attached algae on rocks in close proximity to stream sediments) and fish near the Y-12 Complex; therefore some metal levels may be of ecological relevance.

- Benthic macroinvertebrate community monitoring is a sensitive integrated measure of ecological condition as benthic organisms are directly influenced by both water quality and sediment-related stressors. The limited mobility and relatively long life spans (a few months to more than a year) of most benthic macroinvertebrate species make them ideal for use in assessing the condition of aquatic environments (e.g., Barbour et al. 1999). Monitoring the composition and structure of the benthic macroinvertebrate community, which reflects the recent and long-term history of environmental quality at a site, provides a better assessment of the condition of aquatic environments than results from physical and chemical water quality analyses alone. Two macroinvertebrate monitoring methods will be utilized in EFPC to provide a rigorous spatial and temporal assessment of biological integrity.

- Fish population and community studies can be used to assess the ecological effects of changes in water quality and habitat. These studies offer several advantages over other indicators of environmental quality (Karr 1987) and are especially relevant to assessment of the biotic integrity of EFPC. The primary objectives of fish community monitoring are to characterize the fish communities in the stream and to identify impacts associated with Y-12 Complex operations. Supplemental studies (i.e. fish kill investigations) will be conducted as necessary. Data obtained from this task will be used to 1) document compliance with the classified uses of the receiving streams, 2) provide feedback to management on the effectiveness of pollution abatement actions, 3) help identify causative agents for impacts on stream health, 4) assess potential distribution and abundance of threatened and endangered species in the watershed, and 5) continue to assess recovery of the fish communities.

\section{Methods}

A summary of the major biological monitoring tasks, organisms sampled, field and laboratory methods, and key calculated metrics for the Y-12 Biological Monitoring and Abatement Program Plan is provided in Table 2. Task-specific method information is described below. 
Table 2. Summary of the biological monitoring tasks, organisms sampled, field and laboratory methods, and key calculated metrics for the Y-12 Biological Monitoring and Abatement Program.

\begin{tabular}{|c|c|c|c|c|}
\hline Tasks & Organisms & Field methods & Lab methods & Key metrics \\
\hline Bioaccumulation & $\begin{array}{l}\text { Sunfish (redbreast, } \\
\text { rock bass, or } \\
\text { bluegill) for fillet } \\
\text { analysis. } \\
\text { Stonerollers for } \\
\text { whole body } \\
\text { analysis }\end{array}$ & $\begin{array}{l}\text { Backpack and } \\
\text { boat } \\
\text { electrofishing }\end{array}$ & $\begin{array}{l}\text { Six individual } \\
\text { sunfish fillets or } \\
\text { muscle plugs. } \\
\text { Three composite } \\
\text { whole body } \\
\text { minnows }\end{array}$ & $\begin{array}{l}\text { Average } \\
\text { concentrations } \\
\text { in fish: } \\
\text { mercury, PCBs, } \\
\text { and other } \\
\text { metals }\end{array}$ \\
\hline $\begin{array}{l}\text { Benthic } \\
\text { macroinvertebrate } \\
\text { community }\end{array}$ & $\begin{array}{l}\text { Stream benthic } \\
\text { macroinvertebrate } \\
\text { taxa }\end{array}$ & $\begin{array}{l}\text { TDEC protocol, } \\
\text { kick samples. } \\
\text { ORNL protocol } \\
\text { Hess samples }\end{array}$ & $\begin{array}{l}\text { Taxa sorting, } \\
\text { identification and } \\
\text { enumeration }\end{array}$ & $\begin{array}{l}\text { TDEC biotic } \\
\text { and habitat } \\
\text { indices; Total } \\
\text { richness, EPT } \\
\text { richness; EPT } \\
\text { density }\end{array}$ \\
\hline Fish community & Stream fish taxa & $\begin{array}{l}\text { Backpack and } \\
\text { barge } \\
\text { electrofishing; } \\
\text { Three-pass } \\
\text { removal } \\
\text { method; species } \\
\text { identification, } \\
\text { length-weight, } \\
\text { and enumeration } \\
\text { in field }\end{array}$ & $\begin{array}{l}\text { Small subset } \\
\text { occasionally kept } \\
\text { for species } \\
\text { verification }\end{array}$ & $\begin{array}{l}\text { Species } \\
\text { richness, } \\
\text { density, } \\
\text { biomass. } \\
\text { Sensitive } \\
\text { species } \\
\text { richness and } \\
\text { density. Index } \\
\text { of Biotic } \\
\text { Integrity }\end{array}$ \\
\hline
\end{tabular}

Bioaccumulation Monitoring: The bioaccumulation monitoring effort primarily focuses on evaluating changes in the concentrations of total mercury and PCBs in fish as a result of various actions taken at the Y-12 Complex. The temporal tracking effort, using sunfish, is the main focus of the bioaccumulation task.

Redbreast sunfish (Lepomis auritus) will continue to be the primary species utilized in contaminant tracking studies (Fig. 4), but rock bass (Ambloplites rupestris) or bluegill (Lepomis macrochirus) will also be sampled if redbreast sunfish are unavailable. Sunfish species are ideal fish to monitor changes in bioaccumulation over time or space; they are short-lived and sedentary and thus represent recent exposure to contaminants at the site of collection. As a monitoring tool they provide a reliable measure of change in mercury exposure, bioavailability, and bioaccumulation. Muscle tissue from six individual fish from each site will be analyzed for mercury and/or PCBs. By analyzing fish individually, the confounding factor of fish size and sex can be controlled when making spatial and temporal comparisons. All sample analyses for the bioaccumulation task are performed by DOE approved contract laboratories or in-house, using U.S. Environmental Protection Agency (EPA)-approved procedures. 

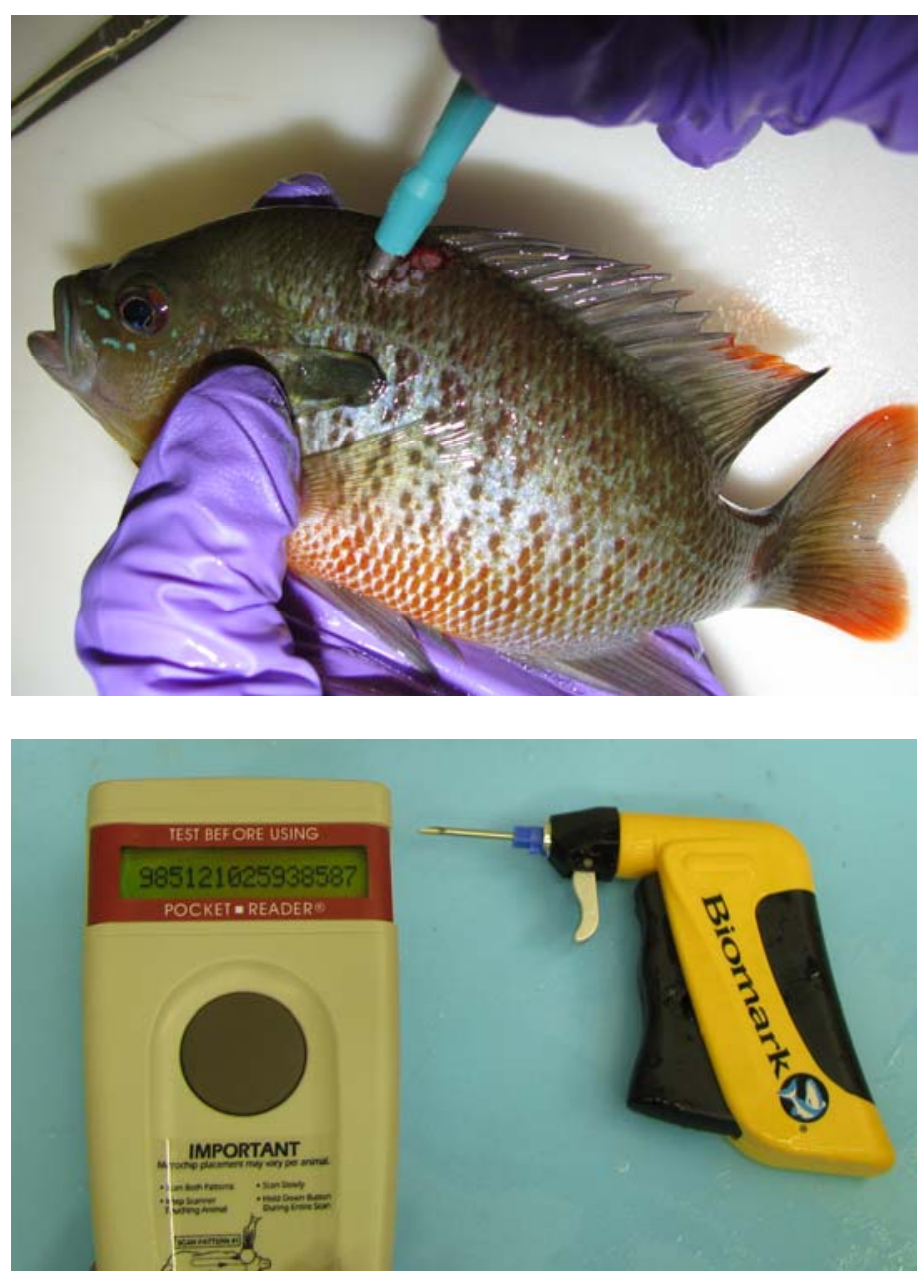

Fig. 4. A biopsy plug being taken from a redbreast sunfish (top), and Passive Integrated Transponder (PIT) tag equipment (bottom) for identifying fish recaptures.

Historically, muscle fillets were taken for contaminant analysis. At sites where PCB analyses are conducted, muscle fillets of sunfish will continue to be taken for this current plan, as a sample size of at least 3 grams is needed for PCB analysis. However, for fish that only need mercury analysis, a nondestructive technique has been used in recent years: a biopsy sample is taken from the live fish, and then the fish are tagged using a Passive Integrated Transponder (PIT) and re-released at the site of capture (Fig. 4). The biopsy technique is an option because conventional mercury analysis only needs $100 \mathrm{mg}$ of tissue. In some instances, the same individual fish has been re-captured and re-analyzed for mercury over a year later, allowing for an assessment of bioaccumulation and growth rates. Since the mid-2000s, redbreast sunfish have been increasingly difficult to collect throughout EFPC and rock bass, which typically have higher mercury concentrations in their tissues, have been collected instead. This makes interpretation of long term trends in mercury concentrations more difficult. Non- destructive sampling for mercury and reducing PCB sampling (which requires sacrificing fish) may alleviate some of the pressure on the redbreast population in EFPC. 
Largescale stonerollers (Campostoma oligolepis) are also advantageous as a bioaccumulation monitoring tool, for different reasons than sunfish. Stonerollers are minnows that graze on periphyton that can contain high concentrations of metals and organics like PCBs, and are therefore a good integrator of food chain and biomagnification processes in the creek. They are additionally a common prey item for larger fish and terrestrial wildlife (e.g., kingfishers, mink, heron), and provide a direct measure of both aquatic and terrestrial organism risks. Three composite samples of whole-body stonerollers, comprising 10 fish in each composite, will be taken from each site. Mercury is analyzed at all stoneroller sampled sites, with PCBs and other metals analyzed in stonerollers at only the uppermost site in EFPC.

A key component of the BMAP is judicious investigation and evaluation of unexpected results or data anomalies. For example, to understand the differences in mercury bioaccumulation between redbreast and rock bass, both species have been sampled at some sites, and an examination of fish size and the relative food web pathways via fish prey (e.g., in stonerollers already collected) has been useful. Assumptions regarding the percent methylmercury in fish tissue will be reexamined for this task, by analyzing a subset of fish tissue for both total mercury and methylmercury. The assumption is that mercury in fillet is near $100 \%$ methylmercury (the more toxic form), but methylmercury may be lower at the upper EFPC sites because of high inorganic mercury inputs. If methylmercury concentrations in fish fillet are lower than the total mercury concentrations, human and environmental risk from these fish may be lower than assumed at some sites.

Benthic Macroinvertebrate Community. Benthic macroinvertebrate community samples will be collected using two procedures: (1) a quantitative method following ORNL protocols that has been used since the BMAP was initiated in 1985 (Smith and Smith 1995; Smith et al. 2011), and (2) a semiquantitative method following protocols developed by the State of Tennessee (TDEC 2011 or current version).

ORNL quantitative protocols provide a strong temporal assessment that will ensure maximum comparability with historical BMAP data. This continuity maximizes the reliability and ensures greater accuracy and confidence in evaluations of the effectiveness of pollution abatement actions that have already been completed and those that will be implemented in the future (e.g., modification in the flow management strategy for upper EFPC). Additionally, results from the long-term BMAP monitoring efforts using the same sampling and sample processing techniques improves the ability to help distinguish ecological changes caused by human actions from those caused by natural phenomena (e.g., floods, drought, etc.). ORNL protocol samples will be collected two times a year with a modified Hess sampler $\left(0.1 \mathrm{~m}^{2}\right)$ fitted with a 363- $\mu \mathrm{m}$-mesh collection net (Fig. 5). Replicate samples will be collected from four randomly selected cells at each site on each sampling date. Samples will be preserved in the field with 80 percent ethanol, and then processed in a laboratory. Processing entails sorting all invertebrates from the sample debris, and then counting and identifying all taxa to the lowest practical taxon (genus for most insects, and genus or higher taxonomic levels for non-insect taxa). Greater detail regarding field and laboratory procedures may be found in Smith et al. 2011.

The State of Tennessee protocol is used by TDEC at a large number of sites across the state. Y-12 BMAP results can therefore be compared with stream results across a large geographic area (including in particular stream results from the Lower Clinch River Watershed), and help determine relative impairment as defined by well-established criteria. The TDEC results are important to stream listings of 

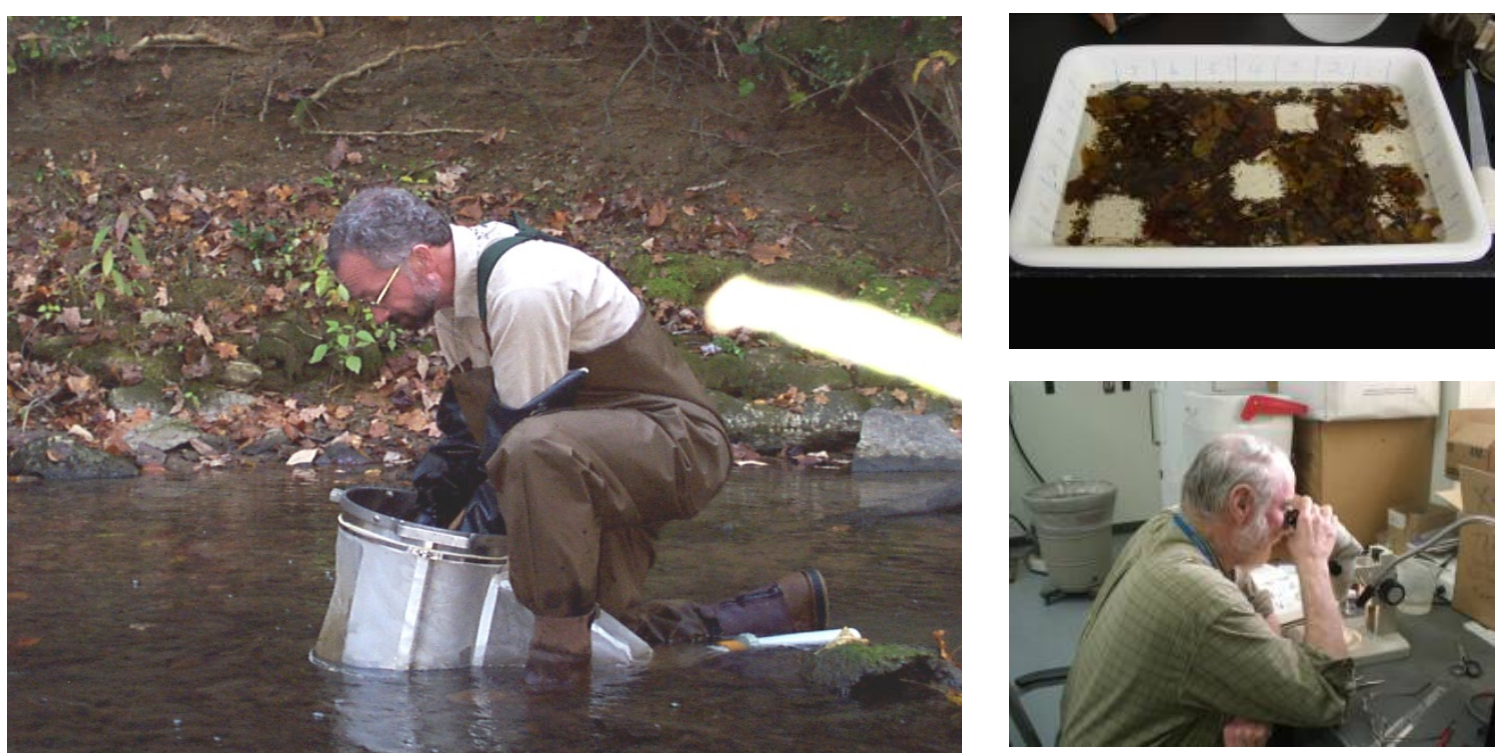

Fig. 5. Benthic macroinvertebrate community task sampling using a Hess sampler (left), TDEC protocol laboratory sorting (top right), and taxa identification (bottom right).

biological impairment that are routinely reported in 303d reports and other state-wide assessments of water quality. Semi-quantitative kick (SQKICK) benthic macroinvertebrate samples will be collected from riffle habitat once annually during the low-flow period (August/September) following the latest TDEC protocols (e.g., TDEC 2011); sample locations will include the same five sites where quantitative samples are collected with ORNL protocols. TDEC protocols will also be followed for processing samples in the laboratory. Laboratory processing involves the use of a random sorting procedure to remove a subsample comprised of 160 to 240 individuals. The sorted invertebrates are then identified to the lowest practical taxon (genus for most taxa) and counted. The samples will be processed in the first half of the next fiscal year which begins on October 1. In addition to collections of invertebrate samples, the quality of stream habitat will be assessed at each site following the current TDEC protocols for habitat assessment (e.g., TDEC 2011). Discharge, dissolved oxygen, conductivity, temperature and $\mathrm{pH}$ at each site will be measured with portable meters concurrently with invertebrate collections (e.g., MarshMcBirney Model 2000 portable flow meter, YSI Model 85 water quality meter, etc.). Finally, vegetative canopy cover also will be determined at each site with a spherical densiometer.

Analyses of routine monitoring results will include evaluations of temporal and spatial trends potentially associated with new abatement activities that will be completed. A variety of descriptive statistics, and statistical tests widely used and available in various statistical software packages, will be used (e.g., metrics such as taxa richness of pollution intolerant invertebrates, total taxa richness, and univariate and multivariate statistical analyses). Samples collected with TDEC protocols will be used to calculate biotic and habitat index values per the latest version of TDEC.

The renewed NPDES Permit stipulates that the BMAP Plan include the professional qualifications of personnel who will perform the benthic macroinvertebrate stream surveys using TDEC protocols. John G. Smith of ORNL is the Principal Investigator of the benthic macroinvertebrate monitoring task who will be 
leading and participating in the collection and occasional processing of the macroinvertebrate samples with BMAP and TDEC protocols. He has B.S. and M.S. Degrees in Biology, specializing in benthic macroinvertebrate community ecology and assessments, and he has over 28 years of experience in designing benthic macroinvertebrate monitoring and assessment studies, sample collection and processing (including taxonomy), water quality assessments, data management and analysis, and report preparation, including publications in peer-reviewed journals.

A majority of samples collected for the benthic macroinvertebrate task will be processed by private consultants selected through an open-bid process. The selected individuals will have expertise in benthic macroinvertebrate sample processing and taxonomy. When possible, consultants with previous experience in processing BMAP samples will be used.

Fish Community Monitoring. Method details for sampling and analysis of the fish community in EFPC is given in Ryon (2011). Sampling of fish is conducted over an approximately 100-m reach of stream using two backpack or one barge electrofishing units (Fig. 6). A 0.64-cm-mesh net is placed across the upper and lower boundaries of the reach to restrict fish movement. Using a standard removal estimate approach, a 5- to 10-person sampling team makes three consecutive passes through the study reach in an upstream direction. If fish numbers captured during the first pass are extremely low or zero, then only one pass is made. However, multiple passes are used in $95 \%$ of the sampling events to improve estimations (Riley et al. 1992). Stunned fish are collected and placed in seine-net boxes during further sampling.

Captured fish are anesthetized with MS-222 (tricaine methanesulfonate), identified, measured (total length), and weighed using Pesola spring scales (Fig. 6). Individuals are recorded by species into 1-cm size classes and if 5 individuals of a species size class is measured and weighed, additional members of that size class are measured but not weighed. At sites with extremely high fish densities (e.g., 2,000 fish in a 100-m reach), the fish are just identified and counted by species after a sufficient number of that species had been measured and weighed (Miranda 2007). A maximum of 300 length measurements are taken per species. After processing fish from all passes, the fish are allowed to recover from the anesthetic and returned to the stream.

Data from fish community monitoring will be used to estimate population size (numbers and biomass per unit area), determine community structure (i.e, species richness and abundance), and estimate production, as needed. An Index of Biotic Integrity (IBI) modified for the Clinch River region and adjusted for the increased flow in EFPC will be used also to analyze fish community impacts.

As a result of the discovery in 2002 of a single individual of a federally-listed fish species, the spotfin chub (Erimonax monachus), BMAP staff involved in fish sampling have been trained to identify this threatened fish as well as other rare fish species. Occasionally other rare fish are encountered in EFPC, especially in the lower section of stream, as evidenced by the recent collection of the tangerine darter (Percina aurantiaca). Although specific targeted sampling for rare fish is not conducted, regular monitoring of downstream sites in EFPC may provide an indication of the continued presence of rare species in the watershed.

A component of the fish community task is evaluation of fish kills when they occur. Fish kills from inadvertent spills were once a common occurrence in UEFPC, but in recent years are relatively rare. A 

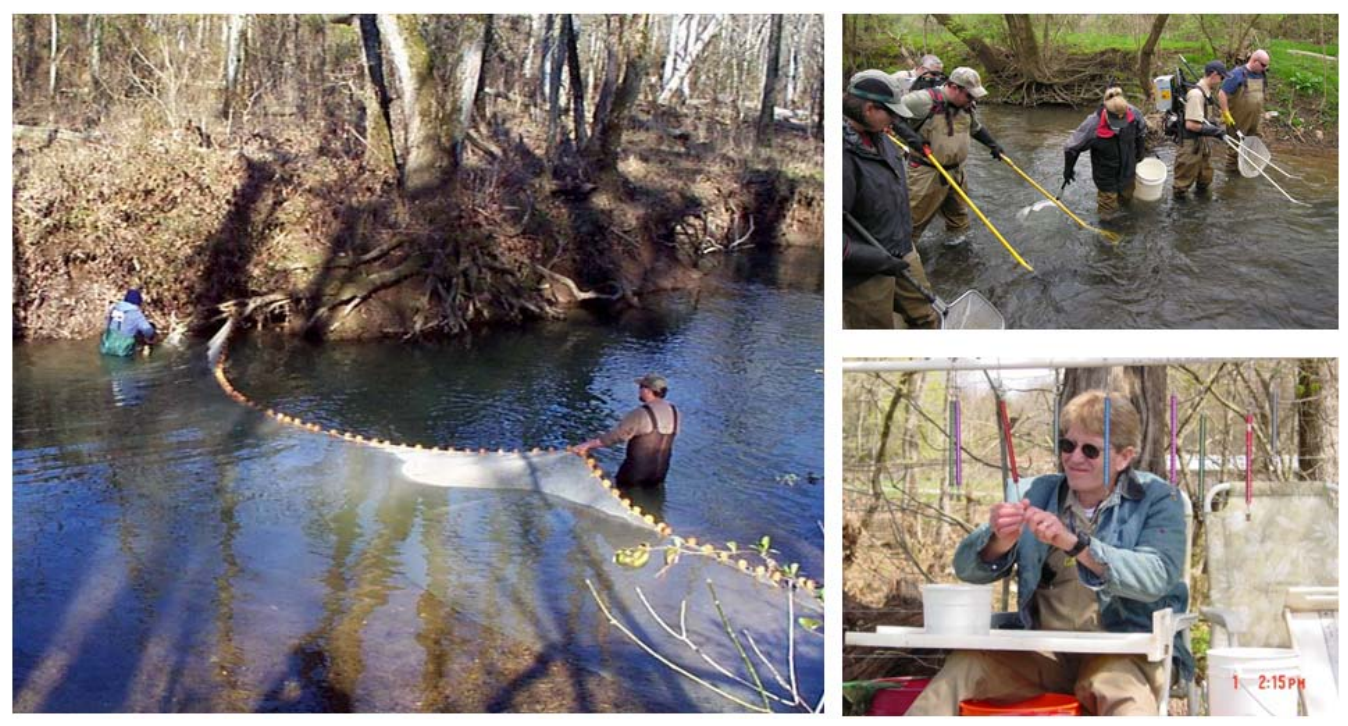

Fig. 6. Setting seine nets for the fish community task (left), backback electrofishing (top right), and processing fish (bottom right).

fish kill in July 2011 in UEFPC is recent evidence that fish kills can still occur at the Y-12 Complex. The high fish densities currently in the upper sections means inadvertent spills or toxicity can impact a greater number of fish than historically (Ryon et al. 2002). Fish kill evaluations include retrieving dead fish, species identification, enumeration, and physiological examination. The information can provide insight as to the cause of the fish kill, and indicate the extent of the fish population impacted by the event.

\section{Sampling Sites and Frequencies}

The BMAP has historically used five primary study sites on EFPC (Fig. 1). Criteria used in the selection of these sites includes (1) location of sampling sites utilized in past studies, (2) known or suspected sources of downstream pollution, (3) proximity to DOE ORR boundaries, (4) concentration of mercury in the adjacent floodplain, (5) appropriate habitat distribution, and (6) access. The sampling sites are located at East Fork Poplar Creek kilometer (EFK) 24.4 and EFK 23.4 [above and below Lake Reality, respectively]; EFK 18.7 (or EFK 18.2), located off the ORR and below an area of intensive commercial and limited light industrial development and just above the area with the highest mercury contamination in the floodplain; EFK 13.8, located approximately $400 \mathrm{~m}$ above the outfall of the Oak Ridge Wastewater Treatment Facility (ORWTF); and EFK 6.3, located approximately $1.4 \mathrm{~km}$ below the ORR boundary and the most downstream site sampled in the creek. Starting in 2013 an additional creek site will be sampled for fish mercury analysis (at EFK 13.0, immediately downstream of the ORWTF), as requested by TDEC in their approval of the BMAP Plan. As the most downstream extent of elevated mercury in fish is in the Clinch River, two sites further downstream, PCK 1.6 in Poplar Creek and CRK 15.0 in the Clinch River, are sampled annually for mercury bioaccumulation only. 
Two additional streams near the Y-12 Complex are also sampled annually using BMAP and TDEC protocols as part of CERCLA-funded studies: Bear Creek and McCoy Branch. To evaluate in-stream contaminant exposure and potential human and ecological risks in the Bear Creek watershed, fish are collected twice a year and analyzed for a suite of metals and PCBs at sampling locations Bear Creek Kilometer (BCK) 3.3, BCK 9.9, and BCK 12.4. Fish and benthic macroinvertebrate communities are monitored twice a year at BCK 3.3, BCK 9.9, BCK 12.4, and NT-3 (north tributary to Bear Creek). In the McCoy Branch watershed, fish and benthic macroinvertebrate communities are monitored twice a year above McCoy Branch Kilometer, (MCK 1.9) and below Rogers Quarry (MCK 1.4 and MCK 1.6). Fish are also collected from Rogers Quarry for contaminant analysis on an annual basis. Details regarding rationale, locations, and monitoring results for these watersheds are provided in the annual Remediation Effectiveness Reports (RERs) and are not summarized further here. As required in the Y-12 Complex NPDES Permit, the BMAP results from these two streams will be reported in the annual BMAP report to TDEC.

The comparison of impacted stream sites to regional reference streams is a key aspect of the BMAP monitoring strategy. EFPC reference streams, including Brushy Fork (BFK 7.6) and Hinds Creek (HCK 20.6), were selected many years ago because of their similar size, geology, hydrology, and proximity to EFPC and they do not receive industrial effluent discharges as EFPC does. However, Brushy Fork and Hinds Creek are located in rural settings and these streams do not represent pristine conditions. As such, they are subject to common ecological impacts often associated with rural settings, such as sedimentation/siltation associated with runoff from disturbed soils, and inputs of nutrients common in fertilizers and land used as pasture for crops or grazing farm animals. As land-use changes occur in the watersheds of the reference streams, and as greater familiarity is gained of regional watersheds, a periodic evaluation of reference stream suitability, and potential alternatives, is an important ongoing process for the BMAP.

The locations and frequency of BMAP sampling varies by task and monitoring approach (Table 3). Mercury sunfish sampling for mercury will be conducted twice a year at four of five EFPC sites and one reference stream, providing important information on mercury levels in fish over time in response to expected changes in water concentrations and flux over the next few years. Other sites, species, and analytes will be evaluated for bioaccumulation annually. Quantitative benthic macroinvertebrate samples following ORNL protocols will be collected biannually (fall and spring) from riffles within permanently established reaches at three sites in EFPC (EFKs 24.4, 23.4, and 13.8), and one site in each of two reference streams including Brushy Fork (BFK 7.6) and Hinds Creek (HCK 20.6). TDEC protocol sampling is conducted annually during the low-flow period (August/September). Quantitative sampling of the fish populations will be conducted by electrofishing at five sites in EFPC and at one reference stream, Brushy Fork. Sampling will be conducted in both the spring (March-May) and fall (SeptemberNovember) at four sites and at the reference site. Annual sampling will be conducted at one site (EFK 24.4) located upstream of Lake Reality. 
Table 3. Summary of the 2012 Y-12 Biological Monitoring and Abatement Program Plan's sampling locations and annual frequencies.

\begin{tabular}{|c|c|c|c|c|c|c|}
\hline \multirow[b]{2}{*}{ Locations } & \multicolumn{3}{|c|}{ Bioaccumulation } & \multicolumn{2}{|c|}{$\begin{array}{c}\text { Benthic } \\
\text { Macroinvertebrate } \\
\text { Community }\end{array}$} & \multirow[b]{2}{*}{$\begin{array}{c}\text { Fish } \\
\text { Community }\end{array}$} \\
\hline & $\begin{array}{l}\text { Sunfish } \\
\text { Mercury }\end{array}$ & $\begin{array}{l}\text { Minnows } \\
\text { Mercury }\end{array}$ & $\begin{array}{c}\text { Sunfish } \\
\text { PCBs }\end{array}$ & $\begin{array}{c}\text { ORNL } \\
\text { Protocol }\end{array}$ & $\begin{array}{c}\text { TDEC } \\
\text { Protocol }\end{array}$ & \\
\hline
\end{tabular}

Upper EFPC

EFK 24.4

EFK 23.4

EFK 18.2

Lower EFPC

1

1

\section{2}

1

1

2

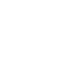

EFK 13.8

EFK 13.0

EFK 6.3

\section{1}

2

1 $1^{\mathrm{b}}$

2

1

2

2

\section{Offsite}

PCK 1.6

CRK 15.0

BFK 7.6

HCK 20.6
1

1

2

1

2

\footnotetext{
${ }^{\mathrm{a}}$ Stonerollers collected from this site will be additionally analyzed for PCBs and other metals, as in past years.

${ }^{\mathrm{b}}$ The largest individual fish from the 6-fish seasonal collection for mercury analyses will be analyzed for PCBs.

EFPC=East Fork Poplar Creek; EFK=East Fork Poplar Creek kilometer; PCK=Poplar Creek kilometer; CRK=Clinch River kilometer; HCK=Hinds Creek kilometer; BFK=Brushy Fork kilometer.

Sunfish to be collected are redbreast sunfish (Lepomis auritus), rock bass (Ambloplites rupestris), and/or bluegill (Lepomis macrochirus), depending on site and availability. Target whole body prey species is largescale stoneroller (Campostoma oligolepis), but other prey species may be substituted or used, if needed.
} 


\section{PROGRAM INTEGRATION}

\section{Approach}

The Y-12 BMAP is implemented at the Y-12 Complex using a highly integrative programmatic approach (Peterson et al. 2011). Integrative elements of the BMAP include:

- Cross program coordination

- Spatial and temporal design

- Sampling methods

- Media types, and

- Adaptive management and decision-making support.

For any monitoring program, there is greater programmatic value when there is effective coordination across regional monitoring programs and the ability to address multiple goals with the same data. Key elements of the BMAP's goals, monitoring strategy, and biological monitoring components and metrics are implemented across the ORR and offsite locations as part of CWA and CERCLA-funded BMAPs near all three DOE facilities in Oak Ridge (as well as other DOE and Department of Defense (DoD) sites across the nation; Peterson 2011). BMAP data address multiple DOE monitoring goals and are reported in site-specific annual BMAP reports, the Annual Site Environmental Report (ASER), and the annual Remediation Effectiveness Report (RER). BMAP data has been extensively used for various ORR Environmental Impact Statements and human and ecological risk assessments. Lastly, benthic macroinvertebrate results and fish-based IBI information is provided to TDEC for watershed-wide and state of Tennessee ecological comparisons.

With a spatial design focus on sampling near-source, at integration points, at boundary areas, and uncontaminated regional reference sites, BMAP results can be put in perspective with other impacted sites on the ORR as well as various reference streams. The use of standardized methods through time has allowed for detailed assessments of temporal change that would not be possible if methods changed from year to year. Biological community monitoring methods are integrative as they reflect the cumulative effects of discharges (reflecting for example contaminant, nutrient, water quality, and habitat effects), even when there are multiple stressors or changing stressors over time. Bioaccumulation methods provide similar benefits in that fish concentrations reflect multiple years of exposure and integrate changes in water contaminant levels as well as changes in microbial activity or food chain effects.

Integrative approaches like biological monitoring techniques provide the most interpretive power when they are closely aligned with water quality monitoring data and operational changes at a facility. The use of biological monitoring data in conjunction with water chemistry sampling provides a number of additional or synergistic benefits (Peterson et al. 2011), including the ability to evaluate cause of impacts. Y-12 BMAP monitoring results have long been presented in context with water quality measures obtained by the Y-12 Compliance Department staff (Stewart et al. 2011).

Long-term biological monitoring programs must balance consistency and flexibility. An adaptive management approach is used by the BMAP where standardization and method consistency are 
maintained, but the program is flexible enough to address changes in regulatory requirements (e.g., use of TDEC invertebrate protocols), take advantage of improved monitoring techniques or technological advances (e.g., use of fish plugs for mercury analysis), and conduct short-term investigations to identify causes of observed impairments (e.g., fish kill investigations). BMAP staff work closely with Y-12 Environmental Compliance and facility operations staff as needed to provide decision support and actionable ecological information of use to plant operations and pollution abatement. The current Y-12 BMAP will continue the emphasis on adaptive management and feedback of monitoring results into management actions to improve plant operations with a goal of continued ecological improvement.

\section{Organization}

The B\&W Y-12 Environmental Compliance Department (ECD) provides environmental technical support services and oversight for Y-12 Complex line organizations to ensure that site operations are conducted in a manner that is protective of workers, the public, and the environment; in compliance with applicable standards, DOE orders, environmental laws and regulations; and consistent with B\&W Y-12's environmental policy and site procedures (DOE 2009). The ECD serves as the B\&W Y-12 interpretive authority for environmental compliance requirements and as the primary point of contact between B\&W Y-12 and external environmental compliance regulatory agencies such as the city of Oak Ridge, TDEC, and the EPA. The ECD implements the monitoring requirements specified in the Y-12 Complex NPDES Permit, including, among many activities, extensive sampling of water.

The BMAP is executed by the ORNL Environmental Sciences Division (ESD) in support of the ECD. ORNL is a world-class scientific research facility and is the largest science and energy national laboratory in the DOE system. The BMAP staff includes multiple experienced researchers at the Masters Degree and PhD levels, some of whom who have been engaged in the Y-12 BMAP since its inception in 1985. The program's findings have been presented in over 200 open literature publications, four books, and over 300 technical reports and conference presentations. The BMAP is closely aligned with, and staff located in, the Aquatic Ecology Laboratory (AEL). The AEL is a unique aquatic research facility located at the west end of ORNL that provides a field deployment and laboratory analysis platform for biological monitoring activities across the ORR. The facility is one of the few aquatic research facilities in the region and includes 9000-square feet of floor space, consisting of flowing stream mesocosms, banks of aquaria, and large tanks for various aquatic studies including those supporting the Y-12 BMAP. Within the facility are analytical, bioindicator, and toxicity testing laboratories, as well as a variety of dissecting scopes and microscopes for fine scale biota identification. Field monitoring assets that can be applied for the Y-12 BMAP include six boats (three electrofishing), one barge electrofisher, ten backpack electrofishers, and various invertebrate sampling devices including a number of Hess and Surber samplers.

\section{Data Management}

The requirements and needs for an integrated BMAP database originate from several sources. The Federal Facilities Agreement and the Tennessee Oversight Agreement (TOA) (OREIS 1993) specifically require development of centralized data facilities that can make data available to regulators and the public. Because of the increasing extent and complexity of the data, there is also a greater need to share data more effectively among BMAP tasks. To meet these needs, an integrated BMAP database has been 
established and populated with historical and ongoing BMAP data. The primary purpose of this database is to facilitate sending the BMAP data to the Oak Ridge Environmental Information System (OREIS). Secondary benefits include support of investigators' needs, providing the capability to perform integrative analyses of BMAP data, and assisting in meeting the requirements of the NPDES permit.

In the approach to data management chosen for BMAP, investigators will continue to acquire the data, assemble basic two-dimensional data sets (e.g., ASCII files, spreadsheets, Statistical Analysis System (SAS) data sets), and perform Quality Assurance/Quality Control (QA/QC) reviews before providing them to the central BMAP database. SAS software is used for ingest of investigator data sets, transformation to standard formats and data summarization, and the integrated BMAP database is now maintained in SAS datasets. ARC/INFO (including ARC/VIEW) software provides geographic information system capability. SAS and ARC/INFO were chosen, in part, because of their effectiveness and broad acceptance but also because these were among the software packages initially used for these purposes by OREIS. Further details about the BMAP database and its use are provided in Christensen et al. (2011).

Data integration activities associated with loading data on contaminant bioaccumulation, ambient toxicity tests, fish communities, and benthic macroinvertebrate communities to the BMAP database, and then to OREIS, are as follows:

- Receive data from Principal Investigators.

- Register data in the Electronic Data Registration System and check into the Revision Control System.

- Prepare files for processing (when needed).

- Read data into SAS.

- Edit data, including adding unique sample identifiers and observation identifiers.

- Standardize data, including adding additional variables, translating site identifiers into BMAP standard nomenclature, and transposing data to put it in the form required by the BMAP and OREIS relational databases.

- Normalize the data, creating one data set for each table that will receive data.

- Check constraints and resolve any that may be violated.

- Load data to the BMAP database.

- Reprocess data, incorporating corrections to or adjustments of the data if needed. This includes occasional incorporation of changes in taxonomic nomenclature.

- Generate OREIS deliverables from the BMAP database in OREIS ready-to-load (RTL) format.

- Check the RTL data sets.

- Transmit data to OREIS, with required paperwork.

- Interact with OREIS to resolve issues that may arise as OREIS processes the deliverables.

- Review OREIS data release packages, and after resolving necessary issues, approve release of the data to the OREIS community.

- Submit OREIS change requests as needed, primarily to handle investigator- requested corrections to or updates of their data or updates of reference tables.

- Perform workstation system administration (including backups), software renewals, and hardware maintenance and replacement, as necessary. 
A number of additional activities related to data integration are either necessary or highly desirable, and these will be carried out as resources permit. To minimize disturbance to the data processing infrastructure used to provide data to OREIS, assistance is provided to OREIS from time to time in areas in which BMAP has expertise (such as taxonomic nomenclature and key attributes) and in areas in which BMAP has an active interest (such as agreement on a structure for and list of results qualifier codes, which could require more extensive changes in our processing infrastructure if not handled in a harmonizing way). Requests for data or information from BMAP investigators are met when possible, particularly in making their data available from OREIS or from the BMAP database. Metadata, in the form of explanatory information about the data, will continue to be developed as resources permit by data management staff or by investigators. Support will continue to be provided to the BMAP investigators and other staff in such areas as accessing the workstation and using the Linux operating system.

Changes in BMAP's data management systems and procedures are anticipated. The BMAP database and processing software may be migrated from Linux to an x86 PC platform as a cost-savings measure. In addition, EnviroData software from Geotech Computer Systems, Inc. has been acquired for BMAP's use. This software will support lab-based BMAP tasks, and over time is also expected to replace some or all of the functions currently based on the BMAP database.

\section{Quality Assurance}

ORNL staff utilizes comprehensive and rigorous quality assurance plans and procedures to implement the Y-12 Complex BMAP. Quality assurance (QA) requirements start broadly at DOE and National Laboratory levels of organization, and become increasingly specific and targeted at programmatic and task-based levels.

ORNL’s Quality Management System (QMS) has been developed to implement the requirements as defined in DOE Order O 414.1D, Quality Assurance and 10 CFR 830 Subpart A, Quality Assurance Requirements, for nuclear facilities, radiological areas, and programs and activities that have the potential to impact nuclear or radiological safety. The methods used for successful implementation of the QMS rely on the integration and implementation of quality elements/criterion flowed-down through multiple management systems and daily operating processes. These management systems and processes are described in the ORNL Standards-Based Management System (SBMS) where basic requirements are communicated to staff. The QMS provides a graded approach to implementation based upon risk.

The Quality Assurance Program (QAP), which is part of the QMS, has been developed to describe how quality requirements at ORNL are implemented. Additionally, the QAP allows for the use of applicable national or international consensus standards for the accomplishment of work. ORNL has adopted ISO 9001:2008 as a Laboratory consensus quality standard. Adoption of ISO 9001:2008 provides the level of rigor and flexibility necessary for the wide range of activities conducted at ORNL, including compliance with ANSI/ASQ E-4, Specifications and Guidelines for Quality Systems for Environmental Data Collection and Environmental Technology Programs, 2004.

The ORNL QAP complies with the QA requirements of the EPA. It addresses the main topic areas in EPA/Q5, EPA Requirements for Quality Assurance Project Plans. It is supported by ESD-QAP-04, ORNL Quality Management Plan for U. S. Environmental Protection Agency Projects, which restructures 
the ORNL QA Program into a format consistent with EPA QA/2, EPA Requirements for Quality Management Plans.

At the programmatic level, the Y-12 BMAP follows the QA requirements specified in the Ecological Assessment Science Team QA Plan. The team plan was developed based on guidance from the ORNL QAP, and is specific to the QA needs associated with field sampling and biological monitoring work. The team plan contains a long list of BMAP Standard Operating Procedures (SOPs). Additional, evenmore-specific customer requirements may be addressed at the project or work activity level through the development of a Quality Assurance Project Plan (QAPP).

\section{Reporting}

As required in the renewed Y-12 Complex NPDES permit, an annual report of BMAP results will be provided to TDEC for review, along with the raw data, taxa lists, and biometric calculations. The report will include results from all three watersheds: EFPC, Bear Creek, and McCoy Branch. The report will include macroinvertebrate taxonomic lists and raw data for samples collected using State protocols, in a readily-usable electronic format. The annual BMAP report will be submitted to the TDEC's Division of Water Pollution Control (WPC) Enforcement and Compliance Section with ORNL's July Discharge Monitoring Report (DMR) of each year.

In order to facilitate communication with the State of Tennessee, two updates per year will be submitted as seasonal status reports of BMAP field activities for each period.

The Y-12 Complex's ECD has long supported regular updates of BMAP results to the public via public forums. As requested by local organizations and the public, the "State of the Creek Address" will continue to be given periodically to ensure BMAP information is provided to regulators and the public in a timely and effective manner. 


\section{REFERENCES}

Barbour, M.T, J. Gerritsen, B.D. Snyder, and J.B. Stribling. 1999. Rapid bioassessment protocols for use in streams and wadeable rivers: periphyton, benthic macroinvertebrates and fish. 2nd Ed. EPA 841-B99-002. U.S. Environmental Protection Agency, Office of Water, Washington, D.C.

Brooks, S.C. and G.R. Southworth. 2011. History of mercury use and environmental contamination at the Oak Ridge Y-12 Plant. Environmental Pollution 159:219-228.

Christensen, S. W., C. C. Brandt, and McCracken, M. K. 2011. Importance of data management in a long-term biological monitoring program. Environmental Management 47: 1112-1124. doi: 10.1007/s00267-010-9576-1.

DOE (U.S. Department of Energy). 2009. The Oak Ridge Reservation Annual Site Environmental Report. DOE/ORO/2327. U.S. Department of Energy, Oak Ridge Office, Oak Ridge, Tennessee. Oak Ridge National Laboratory (UT-Battelle, L.L.C.), Oak Ridge Y-12 National Security Complex (B\&W Technical Services, Y-12, L.L.C.), and East Tennessee Technology Park (Bechtel Jacobs Company L.L.C), Oak Ridge, Tennessee.

Geraghty and Miller, Inc. 1985. Remedial Alternatives for the Bear Creek Valley Waste Disposal Area. Final Report No. Y/SUB/85-00206C/3. Geraghty and Miller, Inc. Tampa, Florida.

Ham, K. D., S. M. Adams, and M. J. Peterson. 1997. Application of multiple bioindicators to differentiate spatial and temporal variability from the effects of contaminant exposure on fish. Ecotoxicology and Environmental Safety. 37, 53-61.

Hinzman, R. L., S. M. Adams, M. C. Black, H. L. Boston, W. Burton, A. J. Gatz, Jr., M. S. Greeley, Jr.,W.R. Hill, J. M. Loar, J. F. McCarthy, M. J. Peterson, M. G. Ryon, J. G. Smith, G. R. Southworth, A.J. Stewart, and V. R. Tolbert. 1993. Second Report on the Oak Ridge Y-12 Plant Biological Monitoring and Abatement Program for East Fork Poplar Creek. Y/TS-888. Oak Ridge Y-12 Plant. Oak Ridge, Tennessee.

Karr, J. R. 1987. Biological monitoring and assessment: A conceptual framework. Environ. Manag. 11:249-256.

Loar, J. M., S. M. Adams, L. J. Allison, J. M. Giddings, J. F. McCarthy, G. R. Southworth, J. G. Smith, and A. J. Stewart. 1989. The Oak Ridge Y-12 Plant Biological Monitoring and Abatement Program for East Fork Poplar Creek. ORNL/TM-10265. Oak Ridge National Laboratory, Oak Ridge, Tennessee.

Loar, J. M., S. M. Adams, L. J. Allison, M. C. Black, H. L. Boston, A. J. Gatz, Jr., R. L. Hinzman, M. A. Huston, B. D. Jimenez, J. F. McCarthy, S. D. Reagan, J. G. Smith, G. R. Southworth, and A. J. Stewart. 1992. First Report on the Oak Ridge Y-12 Plant Biological Monitoring and Abatement Program for East Fork Poplar Creek. Y/TS-886. Oak Ridge Y-12 Plant. Oak Ridge, Tennessee.

Loar, J.M., A.J. Stewart, and J.G .Smith. 2011. Twenty-five years of ecological recovery of East Fork Poplar Creek: Review of environmental problems and remedial actions. Environmental Management 47:6:1010-1020. 
Miranda L.E. 2007. Approximate sample sizes required to estimate length distributions. Transactions of the American Fisheries Society 136(2):409-415.

OREIS (Oak Ridge Environmental Information System). 1993. Draft Data Management Plan for the Oak Ridge Environmental Information System, Version 2.0. ES/ER/TM-39/R1, Environmental Restoration Division, Oak Ridge, Tennessee.

Peterson, M.J. 2011. Introduction to the Biological Monitoring and Abatement Program. Environmental Management 47:6:1005-1009.

Peterson, M.J., R.A. Efroymson, and S.M. Adams. 2011. Long-Term biological monitoring of an impaired stream: Synthesis and environmental management implications. Environmental Management 47:6: $1125-1140$.

Riley, S. C., K. D. Fausch, and C. Gowan. 1992. Movement of brook trout (Salvelinus fontinalis) in four small subalpine streams in northern Colorado. Ecology of Freshwater Fish 1:112-122.

Ryon, M. G., A. J. Stewart, L. A. Kszos, and T. L. Phipps. 2002. Impacts on streams from the use of sulfur-based compounds for dechlorinating industrial effluents. Water, Air, Soil Poll. 136:255-268.

Ryon, M.G. 2011. Recovery of fish communities in a warm water stream following pollution abatement. Environmental Management 47:6: 1096-1111.

Sample, B. E., R. L. Hinzman, B. L. Jackson, and L. Baron. 1996. Preliminary Assessment of the Ecological Risks to Wide-ranging Species on the Oak Ridge Reservation, 1996 Update. DOE/OR/011407\&D2. Oak Ridge National Laboratory. Oak Ridge, Tennessee.

Smith, J.G., C.C. Brandt, and S.W. Christensen. 2011. Long-term benthic macroinvertebrate community monitoring to assess pollution abatement effectiveness. Environmental Management 47:1077-1095.

Smith, M. R., and J. G. Smith. 1995. Biological Monitoring and Abatement Program, Benthic Macroinvertebrate Community Studies Quality Assurance Plan, QAP-X-89- ES-068, Rev. 1, November 1995. Oak Ridge National Laboratory, Oak Ridge, Tennessee.

Stewart, A.J., J.G. Smith, and J.M. Loar. 2011. Long-term water-quality changes in East Fork Poplar Creek, Tennessee: Background, trends, and potential biological consequences. Environmental Management 47:6: 1021-1032.

TDEC (Tennessee Department of Environment and Conservation). 2010. Proposed Final Version, Year 2010 303(d) List (August 2010). Tennessee Department of Environment and Conservation, Division of Water Pollution Control. http://tn.gov/environment/wpc/publications/pdf/2010proposed_final_303dlist.pdf.

TDEC (Tennessee Department of Environment and Conservation). 2011. Quality system standard operating procedure for macroinvertebrate stream surveys. Tennessee Department of Environment and Conservation, Division of Water Pollution Control.

http://www.state.tn.us/environment/wpc/publications/pdf/bugsop11.pdf. 